Atmos. Chem. Phys., 10, 209-218, 2010

www.atmos-chem-phys.net/10/209/2010/

(C) Author(s) 2010. This work is distributed under

the Creative Commons Attribution 3.0 License.

\title{
Aerosols that form subvisible cirrus at the tropical tropopause
}

\author{
K. D. Froyd ${ }^{1,2}$, D. M. Murphy ${ }^{1}$, P. Lawson ${ }^{3}$, D. Baumgardner ${ }^{4}$, and R. L. Herman ${ }^{5}$ \\ ${ }^{1}$ NOAA Earth System Research Laboratory, Chemical Sciences Division, Boulder, CO, USA \\ ${ }^{2}$ Cooperative Institute for Research in Environmental Science, University of Colorado, Boulder, CO, USA \\ ${ }^{3}$ SPEC Incorporated, Boulder, CO, USA \\ ${ }^{4}$ Universidad Nacional Autonoma de Mexico, Ciudad Universitaria, Mexico City, Mexico \\ ${ }^{5}$ Jet Propulsion Laboratory, California Institute of Technology, Pasadena, CA, USA
}

Received: 11 September 2009 - Published in Atmos. Chem. Phys. Discuss.: 29 September 2009

Revised: 16 December 2009 - Accepted: 17 December 2009 - Published: 12 January 2010

\begin{abstract}
The composition of residual particles from evaporated cirrus ice crystals near the tropical tropopause as well as unfrozen aerosols were measured with a single particle mass spectrometer. Subvisible cirrus residuals were predominantly composed of internal mixtures of neutralized sulfate with organic material and were chemically indistinguishable from unfrozen sulfate-organic aerosols. Ice residuals were also similar in size to unfrozen aerosol. Heterogeneous ice nuclei such as mineral dust were not enhanced in these subvisible cirrus residuals. Biomass burning particles were depleted in the residuals. Cloud probe measurements showing low cirrus ice crystal number concentrations were inconsistent with conventional homogeneous freezing. Recent laboratory studies provide heterogeneous nucleation scenarios that may explain tropopause level subvisible cirrus formation.
\end{abstract}

\section{Introduction}

Optically thin cirrus are a common feature of the tropical troposphere layer (TTL) (Fueglistaler et al., 2009; Dessler et al., 2006; Liu, 2007). Cirrus with very low optical densities $(\tau<0.03)$, often termed subvisible cirrus (SVC), are widespread laminar features that occur primarily in the tropical tropopause region. SVC can form in situ (Pfister et al., 2001; Schwartz and Mace, 2009) or as a consequence of recent convection (Dessler and Yang, 2003; Garrett et al., 2004; Massie et al., 2002). These cirrus regulate the vertical

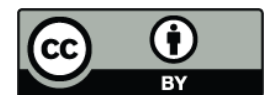

Correspondence to: K. D. Froyd (Karl.Froyd@noaa.gov) transport of water vapor (Jensen and Pfister, 2004; Jensen et al., 1996; Luo et al., 2003) as well as aerosols and condensable gases into the stratosphere. The radiative properties of thin cirrus can influence the local thermal budget and drive dynamics of the tropopause region (Comstock et al., 2002; Hartmann et al., 2001; Jensen et al., 1996; McFarquhar et al., 2000).

Knowledge of SVC formation mechanisms is hampered by limited field observations of aerosol size, composition, and ice-forming capability in the tropical upper troposphere. Relative humidities well above ice saturation are frequently found in clear air in the tropical tropopause region and imply a shortage of effective heterogeneous ice nuclei (IN). Furthermore, measured relative humidities near the tropopause (185-204 K) are often near or may exceed levels required for homogeneous freezing of soluble aerosols (Jensen et al., 2005; Krämer et al., 2009). The onset of homogeneous freezing would convert a large fraction of accumulation mode aerosols to ice crystals and would be largely independent of aerosol composition. However, in simulations of SVC formation, introducing small concentrations of heterogeneous IN more accurately reproduced thin cirrus occurrence, persistence, and microphysical properties (Jensen et al., 2001, 2008; Karcher, 2002, 2004). Jensen et al. (2009b) analyzed recent measurements of tropopause level SVC crystal sizes and concentrations using a parcel model and evaluated probable nucleation scenarios. A summary of microphysical properties of SVC is given by Lawson et al. (2008).

Single particle information is particularly important for studying ice nucleation since the onset of freezing can vary greatly for different aerosol types that are often externally mixed. Also, direct measurement of ice crystal residue is critical to determining nucleation mechanisms. For instance,

Published by Copernicus Publications on behalf of the European Geosciences Union. 
by measuring only out-of-cloud aerosols a subset of particularly effective ice-forming aerosols present at the 1 in 500 level could be overlooked yet could still be the dominant iceforming aerosol type.

Recently, we reported out-of-cloud aerosol composition measurements in the tropical upper troposphere and lower stratosphere (Froyd et al., 2009). Here we present composition measurements of aerosols that froze to form SVC particles near the tropical tropopause. Most tropopause level cirrus in this study were not directly associated with recent convective events and are presumed to have formed in situ from aerosols that slowly ascended through the tropical tropopause layer (TTL). This observation is based on (1) in situ data that did not show lower tropospheric characteristics for long-lived gas phase species (Park et al., 2007), shortlived gases (Ridley et al., 2004), or aerosol composition; (2) minimal convective influence using a trajectory-based analysis (Froyd et al., 2009); and (3) flight camera and satellite imagery analysis. The sizes and chemical signatures of the cirrus-forming aerosols are compared to interstitial and outof-cloud aerosols. From these compositional observations we comment on likely nucleation mechanisms for subvisible cirrus formation.

\section{Measurement techniques}

The NOAA PALMS (Particle Analysis by Mass Spectrometry) instrument is a single particle mass spectrometer that measures online aerosol composition and size for diameters $0.25-3 \mu \mathrm{m}$. Individual particles scatter light from an continuous laser beam, which triggers a pulse from an ionizing laser. Ions are extracted and analyzed with a time-offlight mass spectrometer, producing one complete mass spectrum per particle. Aerodynamic diameters are measured for most particles. PALMS can distinguish between different aerosol types in an external mixture, and chemical components within aerosols can also be studied. The PALMS instrument was deployed on the NASA WB-57 aircraft during the CR-AVE (Costa Rica Aura Validation Experiment) campaign in Jan-Feb 2006. See Murphy et al. (2006a) for modifications to the original flight instrument (Thomson et al., 2000).

A combination aerosol/counterflow virtual impactor (CVI) inlet (Cziczo et al., 2004b) was used to alternately sample ambient aerosols or cloud particles. The $24 \mathrm{~cm}$ long, $2 \mathrm{~mm}$ i.d. inlet was housed in the center of a $88.5 \mathrm{~cm}$ long, $5 \mathrm{~cm}$ i.d. sampling duct extending from the WB-57 nose in which air flowed near aircraft speed. In clear air aerosols were sampled directly with an inlet residence time of $70 \mathrm{~ms}$. In cloudy regions, a counterflow of filtered air was activated to reject interstitial aerosols and selectively sample cloud particles. Cloud particles were then heated to remove water, and remaining cloud "residual" particles $(d>0.25 \mu \mathrm{m})$ were characterized by PALMS. Turning off the counterflow within
SVC effectively sampled both small ice crystals and predominantly ( $>90 \%)$ interstitial aerosol. Inlet mode switching was automatic during flight, but CVI sampling time could be increased manually by the WB-57 instrument operator in cloudy regions.

The CVI deployed during CR-AVE was particularly well suited for sampling SVC crystals. Tropopause level cirrus contain smaller crystals than anvil cirrus associated with a convective system (Lawson et al., 2008). Ice crystals 10$50 \mu \mathrm{m}$ in diameter (maximum dimension) comprise the peak of the SVC mass distribution, and crystals $>30 \mu \mathrm{m}$ are $<3 \%$ by number. The effective sampling range of the CVI was approximately $5-25 \mu \mathrm{m}$. The lower sampling size limit is set by the counterflow, and the upper limit is controlled by particle stopping distance and evaporation time within the CVI inlet. Cloud particles larger than $25 \mu \mathrm{m}$ will impact upon a tubing bend that is downstream of the sampling pickoff running to PALMS.

Convective clouds and anvil cirrus can be problematic for in situ sampling from high speed aircraft because large ice crystals impact on inlet walls and leading edges. Not only do ice crystals shatter and alter the measured cloud particle size distribution (Jensen et al., 2009a), but crystals with enough mass ablate pieces of inlet material that can then be mistaken for cloud residuals (Murphy et al., 2004). During previous PALMS flight studies within anvil cirrus $(\mathrm{Cz}-$ iczo et al., 2004a), stainless steel particles were efficiently generated from crystal impaction on the CVI inlet. These micron-sized contamination particles can be identified with composition-resolving instruments such as PALMS or electron microscope analysis provided the technique is sensitive to the contaminant. For the current study, CVI inlet surfaces were plated with gold. In laboratory studies (Murphy et al., 2004), secondary particle production from ice impaction onto gold was significantly reduced compared to stainless steel, presumably due to the more ductile nature of gold. Consequently, contamination data rates within anvil cirrus during CR-AVE were reduced compared to previous deployments. Also, gold provides a unique composition tracer to identify particles generated from inlet walls. The majority of contamination particles were generated within the CVI inlet, but in dense ice clouds with number modes sizes $>100 \mu \mathrm{m}$, a few particles contained signatures identified as fiberglass from the inner walls of the sampling duct or paint from the duct shroud. Examples of aerosols with secondary material are given in Fig. 1. Positive aerosol spectra were flagged as contaminated when any of the following criteria were met: (1) $\mathrm{Au}^{+}$ions were detected (12\% of contamination particles), (2) signatures from an internal o-ring were observed as $\mathrm{Si}^{+}$and $\mathrm{SiO}^{+}$with their respective isotopes in the absence of other metals (48\%), (3) very intense $\mathrm{Fe}^{+}$signals were observed in combination with $\mathrm{Mo}^{+}, \mathrm{Cr}^{+}$, or $\mathrm{Ni}^{+}$, indicating stainless steel (11\%), (4) combinations of $\mathrm{Sn}^{+}, \mathrm{Sb}^{+}, \mathrm{Ni}^{+}$, $\mathrm{Zn}^{+}$, and $\mathrm{Cu}^{+}$were observed at $>50$ times their usual intensities (10\%). Additionally, all aerosol spectra were rejected 

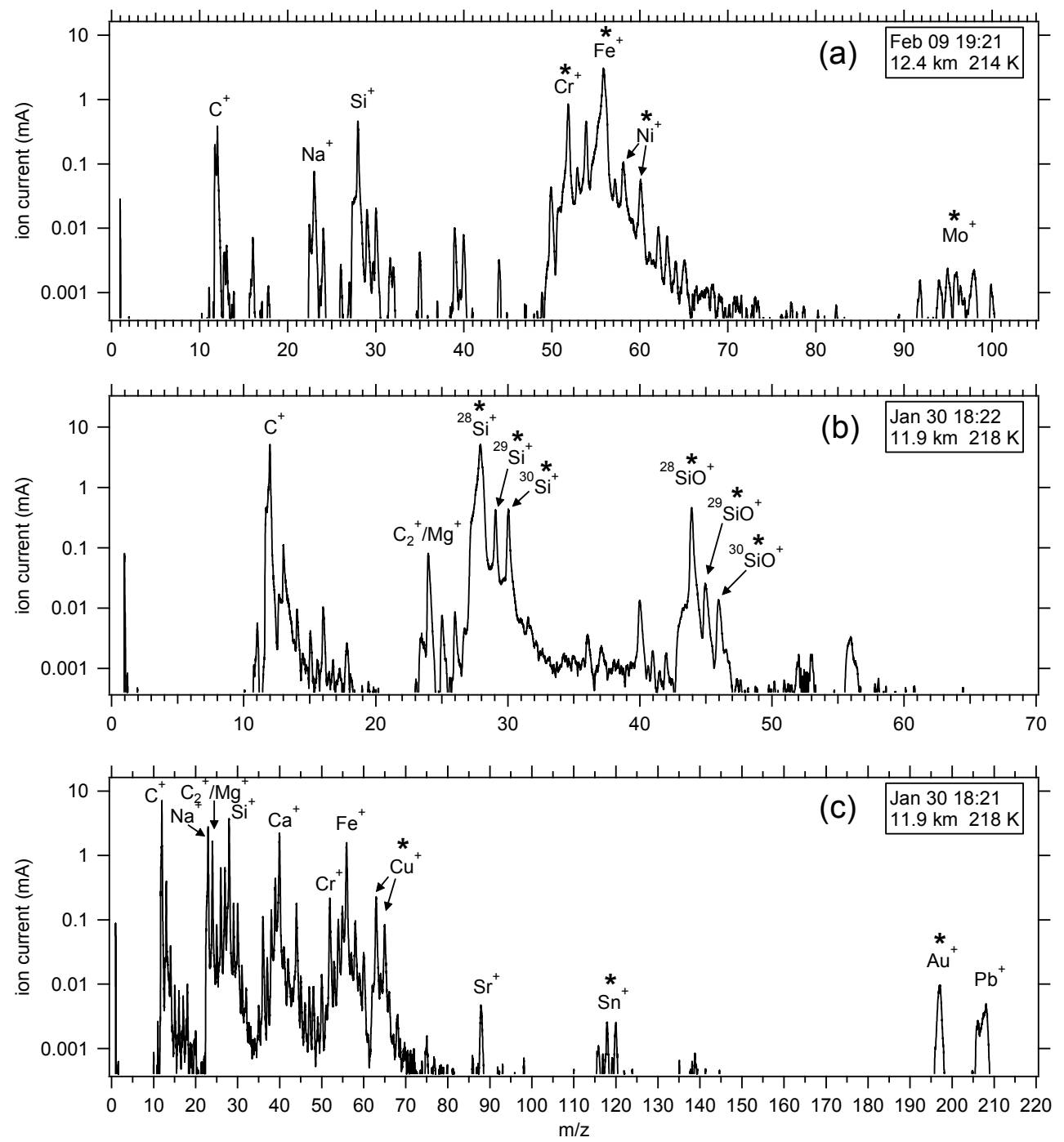

Fig. 1. Contamination signatures from CVI sampling in dense ice clouds. (a) Stainless steel. (b) A nearly pure silicon particle probably from an o-ring inside the CVI. (c) An internal mixture of atmospheric mineral dust and inlet metals. ${ }^{*}$ Denotes contamination signatures.

in regions where $>30 \%$ of spectra showed contamination $(19 \%)$.

One particularly difficult aspect of cloud residual composition analysis is that contamination signatures often appear as minor components of otherwise realistic atmospheric aerosols. Apparently, ice crystal impaction events can generate internal mixtures of the original ice residual with inlet material (Fig. 1c). Signals from many of the contamination metals are $\ll 1 \%$ of the total ion current and probably represent a similarly small fraction of aerosol mass, yet these are not observed outside clouds in, e.g., mineral dust spectra, and they clearly result from secondary particle generation on inlet surfaces. This has important implications for electron microscopy, ion chromatography, or single particle analysis of captured cloud residuals where minor metal components may be overlooked. Figure 2 shows how contamination from ice crystal shattering is a function of cloud ice water content and ultimately, crystal size.

Subvisible cirrus particles are $\sim 100-1000$ times less abundant than TTL aerosols. Our measurement technique relies on a large concentration enhancement $(\sim \times 160)$ by the $\mathrm{CVI}$ to achieve reasonable cloud particle sampling rates. Because PALMS detects aerosols by light scattering, detection efficiency is a strong function of size. Aerosols with $d=0.25 \mu \mathrm{m}$ were detected with $<1 \%$ efficiency, whereas 10 $50 \%$ of $>0.5 \mu \mathrm{m}$ aerosols were detected. If we assume that cloud residual particles have a size distribution typical of the background aerosol and are larger than $100 \mathrm{~nm}$, then PALMS must be sampling in CVI mode for $3 \mathrm{~min}$ to evaluate 10 SVC particles. Ice nucleation can be strongly size dependent, where only the largest aerosols freeze. In these cases the PALMS size range may encompass a large fraction of 


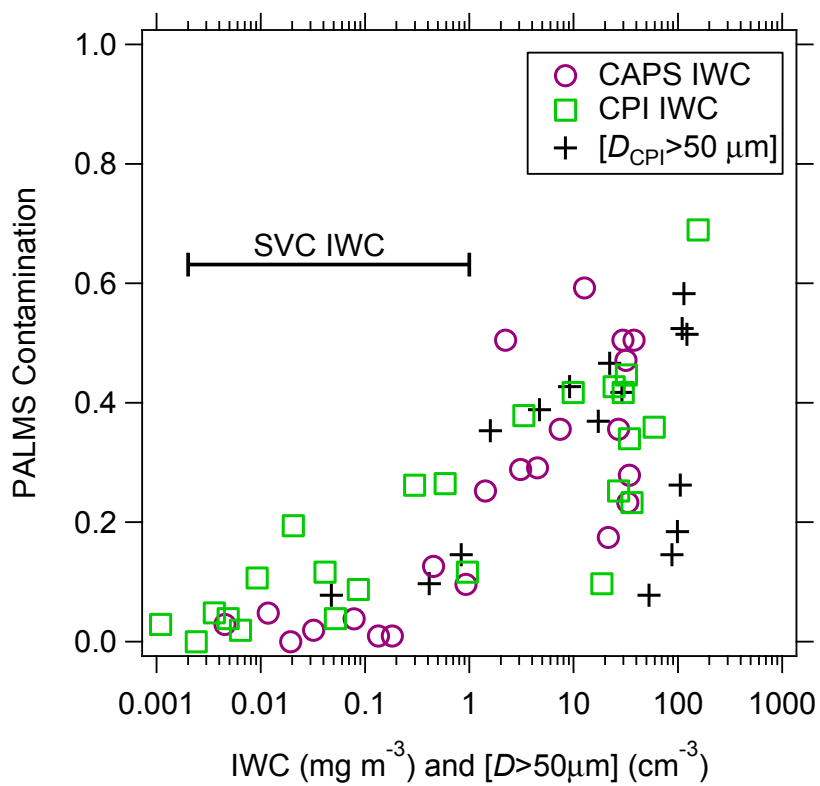

Fig. 2. Fraction of cloud residue particles showing contamination signatures for all ice clouds above $6 \mathrm{~km}$. Low ice water content (IWC), and ultimately, low concentrations of ice crystals $>50 \mu \mathrm{m}$ limited shattering artifacts within SVC. WB-57 aircraft speeds were $150 \mathrm{~m} / \mathrm{s}$ at $10 \mathrm{~km}$ altitude, increasing to $200 \mathrm{~m} / \mathrm{s}$ above $15 \mathrm{~km}$.

the cloud-forming aerosol, and heterogeneous IN should be observed with high relative efficiency.

The CVI must reject ambient and interstitial aerosols with a very high efficiency in order to identify particles detected within SVC as cloud residuals. In the TTL and SVCforming regions $(12-17.5 \mathrm{~km})$ the PALMS acquisition rate while sampling outside cloud with the counterflow on was $<0.000074 \mathrm{~Hz}$. The average aerosol rate outside cloud with no counterflow was $0.14 \mathrm{~Hz}$. Adjusting for inlet aspiration efficiencies, the CVI inlet rejected TTL aerosols with an efficiency $>99.99 \%$ ( 1 in 11250 ). This is similar to previous determinations of $>99.98 \%$ in the subtropical upper troposphere (Cziczo et al., 2004b). Similarly, the data rate with the counterflow on was 800 times higher during SVC penetrations than outside cloud.

It is difficult to calculate the fraction of SVC crystals detected by PALMS as residuals. An accurate determination would depend on several high-order factors including the sub-isokinetic inlet aspiration efficiency, ice crystal stopping distances and heating rates, PALMS size-dependent detection efficiency, and the unknown size distribution of SVC residues. For a rough indication of SVC detection, we convert the detection rate for SVC residuals of $0.062 \mathrm{~Hz}$ into an ambient concentration. By then comparing to ambient crystal concentrations, we estimate that PALMS is detecting residuals for $\sim 2 \%$ of $5-25 \mu \mathrm{m} \mathrm{SVC} \mathrm{crystals.} \mathrm{This} \mathrm{number} \mathrm{is} \mathrm{within}$ the PALMS detection efficiency range for particles $>250 \mathrm{~nm}$ ( $<1 \%$ to $\sim 10 \%)$ and provides some confidence that a sub-

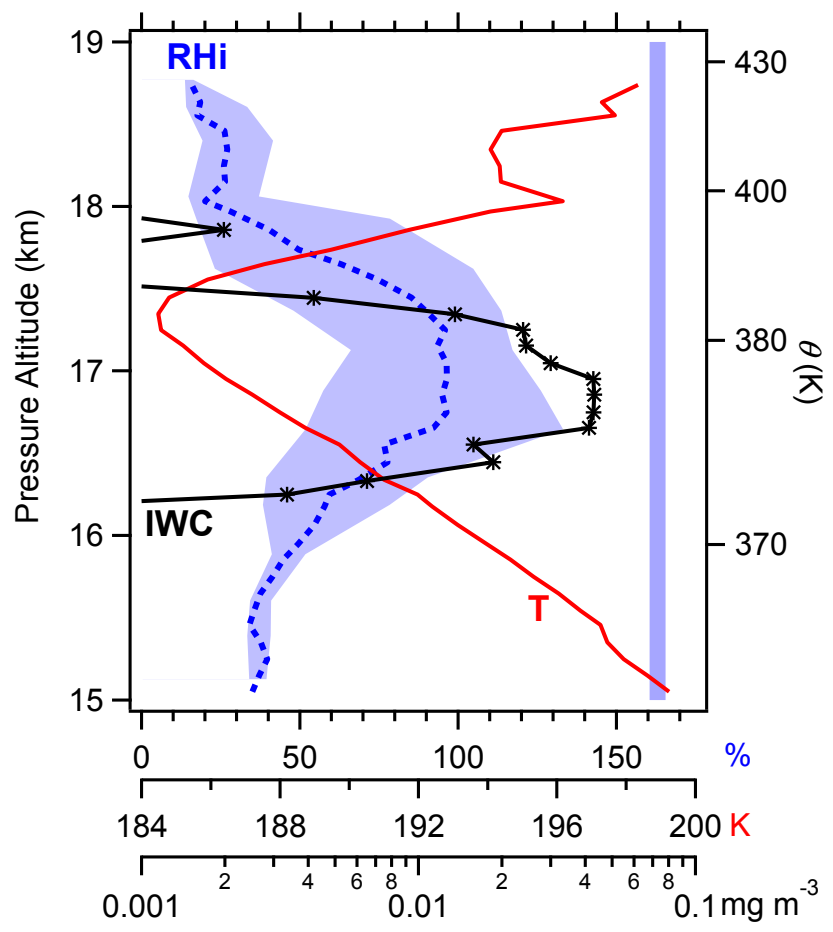

Fig. 3. Average vertical profile for an extensive subvisible cirrus system encountered by the aircraft on 2 February 2006. SVC ice water content (IWC, starred line) is averaged from both 2D-S channels. Mean RHi (dashed line) is calculated from JLH water vapor using Murphy and Koop (2005), and the shaded region encompasses the full range of measurements. The homogeneous freezing limit (vertical bar) is shown for soluble $300 \mathrm{~nm}$ aerosols (Koop et al., 2000). $T$ and RHi data include regions both within and outside cloud.

stantial fraction of the residuals are within the PALMS size range. It is expected that residuals detected using the current method are representative of the residual population and not a special subset.

The NASA JPL Laser Hygrometer (JLH) is an open path instrument that measures water vapor absorption from a nearinfrared laser to determine water vapor mixing ratio (May, 1998). The laser is scanned at $8 \mathrm{~Hz}$ across a strong water vapor absorption line $\left(7299.43 \mathrm{~cm}^{-1}\right)$, and modulated at $128 \mathrm{kHz}$ for sensitive harmonic detection at $256 \mathrm{kHz}$. There is negligible background signal from cloud particles in low density cirrus because this narrow absorption line is specific to water vapor. Furthermore, the harmonic signal is normalized to the power reaching the detector, which accounts for scattering losses due to ice. Absorption data for CR-AVE were calibrated by operating the instrument under similar conditions inside a stainless steel chamber, and flowing a known water vapor/air mixture through the chamber (Troy, 2007). These careful laboratory measurements led to a revision of the JLH data originally submitted to the CR-AVE data archive, to be presented in a future publication. 
Table 1. Composition of ice residues and unfrozen aerosols during SVC encounters.

\begin{tabular}{|c|c|c|c|c|c|c|c|c|c|c|c|}
\hline & $\begin{array}{c}\text { Number of } \\
\text { PALMS } \\
\text { spectra }\end{array}$ & $\begin{array}{l}\text { Sulfate- } \\
\text { organic }\end{array}$ & $\begin{array}{l}\text { Biomass } \\
\text { burning }^{\text {a }}\end{array}$ & $\begin{array}{c}\text { Mineral } \\
\text { dust }\end{array}$ & $\begin{array}{l}\text { Meteoric } \\
\text { material }^{\mathrm{a}}\end{array}$ & $\begin{array}{l}\text { Sea } \\
\text { salt }\end{array}$ & $\begin{array}{c}\text { Elemental } \\
\text { carbon }\end{array}$ & Other & $\begin{array}{l}\text { Sulfate } \\
\text { mass } \\
\text { fraction }^{b}\end{array}$ & $\begin{array}{l}\text { Organic } \\
\text { mass } \\
\text { fraction }^{b}\end{array}$ & $\begin{array}{c}\mathrm{NH}_{4}^{+}: \mathrm{SO}_{4}^{2-} \\
\quad \text { ratio }^{\mathrm{b}}\end{array}$ \\
\hline \multicolumn{12}{|l|}{2 February event } \\
\hline \multirow[t]{2}{*}{ SVC residue } & $(+) 40$ & 38 & 0 & 1 & 0 & 0 & 0 & 1 & - & - & - \\
\hline & $(-) 58$ & 57 & - & 1 & - & 0 & 0 & 0 & 0.36 & 0.64 & $\geq 2$ \\
\hline unfrozen & (+) 161 & 139 & 21 & 1 & 0 & 0 & 0 & 0 & - & - & - \\
\hline aerosol & (-) 197 & 197 & - & 0 & - & 0 & 0 & 0 & 0.50 & 0.50 & $\geq 2$ \\
\hline \multicolumn{12}{|l|}{ All SVC } \\
\hline \multirow[t]{2}{*}{ SVC residue } & (+) 51 & 46 & 1 & 3 & 0 & 0 & 0 & 1 & - & - & - \\
\hline & $(-) 76$ & 75 & - & 1 & - & 0 & 0 & 0 & 0.40 & 0.60 & $\geq 2$ \\
\hline unfrozen & (+) 444 & 366 & 73 & 3 & 0 & 0 & 0 & 2 & - & - & - \\
\hline aerosol & $(-) 429$ & 429 & - & 0 & - & 0 & 0 & 0 & 0.51 & 0.49 & $\geq 2$ \\
\hline
\end{tabular}

${ }^{\text {a }}$ The metallic components of particles with biomass burning or meteoric material are not detected in negative ion mode, and consequently, these aerosols are usually classified as sulfate-organic.

${ }^{\mathrm{b}}$ Relative mass abundance of sulfate and organic material, and sulfate neutralization are determined from negative ion spectra.

SVC ice crystal size distributions and ice water content were measured using the Cloud Aerosol and Precipitation Spectrometer (CAPS, $d=0.5-1550 \mu \mathrm{m}$ ) (Baumgardner et al., 2001 ) and the 2D-S two-dimensional stereo optical probe (5$1400 \mu \mathrm{m})$ (Lawson et al., 2006).

\section{In situ sampling of subvisible cirrus}

Tropopause level cirrus clouds were encountered throughout the CR-AVE campaign. SVC were typically $\leq 1 \mathrm{~km}$ thick and centered around the level of maximum relative humidity located just below the cold point tropopause. SVC did not extend more than a few hundred meters above the tropopause. Most cirrus in the tropopause region were not directly associated with deep convection and are presumed to have formed in situ. Isolated cirrus layers that were remnants of recent convective systems were also observed at lower altitudes in the TTL. Figure 3 details an extensive $(>500 \mathrm{~km})$ tropopause subvisible cirrus layer encountered on 2 February between Central America and the Galapagos.

In a recent study (Froyd et al., 2009), we reported measurements of aerosol composition of the tropical upper troposphere and lower stratosphere and discussed source regions and mechanisms. Tropical upper tropospheric aerosol particles were predominantly internal mixtures of sulfate and organic material. Organic material was highly oxidized and often comprised a larger fraction of the aerosol mass than sulfate. Sulfate was partially or fully neutralized, and estimated $\mathrm{NH}_{4}^{+}: \mathrm{SO}_{4}^{2-}$ ratios suggested that letovicite $(3: 2)$ and ammonium sulfate $(2: 1)$ were the most common forms of sulfate. Other particle types such as biomass burning aerosol, mineral dust, meteoric material, and stratospheric sulfuric acid were present as minor fractions of an external mixture with the sulfate-organic aerosol. Outside of regions influenced by recent continental convection, aerosols showed aging signatures consistent with slow ascent through the TTL over a period of several weeks (Fueglistaler et al., 2009; Park et al., 2007).

Figure 4 and Table 1 compare compositional characteristics of SVC particle residues and unfrozen aerosols during the 2 February encounter. Unfrozen aerosols include interstitial aerosols sampled within SVC as well as aerosols in nearby cloud-free air within the same altitude range. Particle type classifications are based on positive ion mass spectral features described previously (Hudson et al., 2004; Froyd et al., 2009). Subvisible cirrus formed overwhelmingly from freezing of the dominant sulfate-organic aerosol type.

Aerosols with biomass burning signatures were underrepresented in SVC residue. Data from the current study are limited such that we cannot definitively exclude freezing of any biomass burning aerosols. However, these observations are consistent with previous measurements from a cirrus encounter at $14.5 \mathrm{~km}$ where potassium-rich particles were also underrepresented in ice residues (Cziczo et al., 2004b). Biomass burning aerosols are highly organic but also contain small fractions of insoluble inorganic material and sometimes inclusions of elemental carbon that might promote heterogeneous freezing. Here we find no evidence that biomass burning aerosols are efficient IN under these conditions. Furthermore, this observation does not support the notion that the sulfate-organic aerosols froze because they contained small elemental carbon inclusions.

Lower tropospheric aerosols such as mineral dust were not significantly enhanced in subvisible cirrus residues. Furthermore, interstitial dust aerosols were occasionally observed within SVC. In contrast, Cziczo et al. (2004b) found large enhancements of both mineral dust and sea salt in anvil cirrus residues (Fig. 4b). For the tropopause region described here, mineral dust did not possess a substantial advantage to 


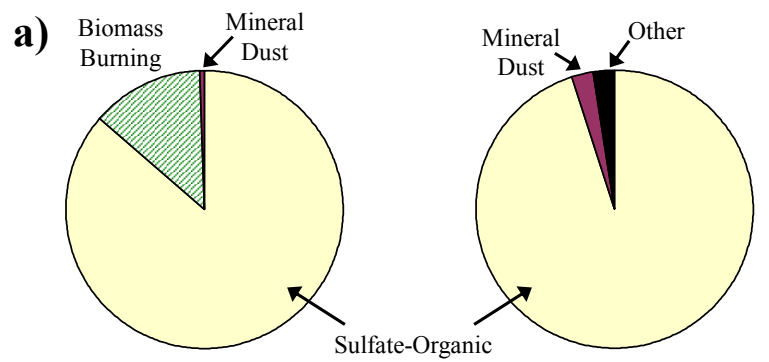

Unfrozen Aerosol Subvisible Cirrus Residue

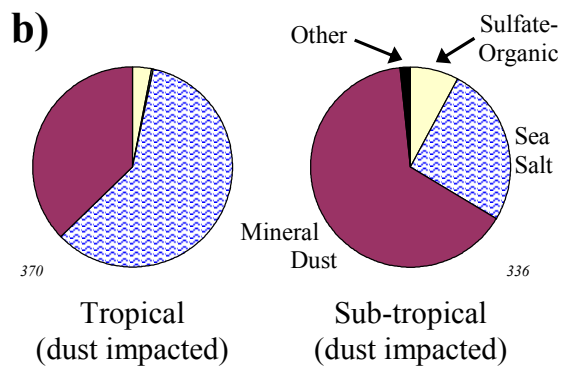

Anvil Cirrus Residue

Fig. 4. Aerosol types in the tropical tropopause region. (a) Subvisible cirrus residues from the 2 February SVC layer at $16.0-17.4 \mathrm{~km}$ are compared to unfrozen aerosols. (b) Residues from several anvil cirrus encounters at lower altitudes, $12-14 \mathrm{~km}$. Anvil ice crystal residues have different compositions than tropopause level cirrus and showed disproportionately high mineral dust and sea salt compared to the background aerosol (not shown, similar to a). Subtropical data are reproduced from Cziczo et al. (2004b). See Table 1 for statistics.

freezing over other aerosol types. It is likely that effective IN were removed from the aerosol population lower in the TTL. Many of the dust spectra showed evidence of organic and sulfate coatings, which probably reduced their effectiveness as heterogeneous IN (Mohler et al., 2008; Cziczo et al., 2009).

Acidic sulfate aerosols and meteoric material from the stratosphere were not found in either the SVC residue or the nearby unfrozen aerosol. As a CR-AVE mission average, 5\% of detected aerosols within $1 \mathrm{~km}$ below the tropopause originated from the stratosphere. The air in the region of SVC formation appeared to have unusually low stratospheric influence, probably because mixing of dry stratospheric air lowers the relative humidity and suppresses SVC formation.

Figure 5 compares mass spectra and aerodynamic size of the sulfate-organic particle type for cirrus residue and unfrozen aerosol. The sulfate-organic mixtures that froze did not appear chemically unique, and cirrus residue spectra were very typical of TTL aerosol. Sulfate was highly neutralized and probably in the form of ammonium sulfate. Nitrogen content was relatively high due to both ammonium and gas phase nitric acid uptake. Relative mass fractions of sul- fate and organic material were 50/50\% for unfrozen aerosols and $36 / 64 \%$ for SVC residue. Although these averages are not statistically different ( $n=197$ and 57), they indicate that ice formation was not initiated only by sulfate-rich aerosols. This is in contrast to anvil cirrus residues where aerosols with higher sulfate content preferentially froze (Cziczo et al., 2004b). Signatures of mercury and halogens (Murphy et al., 2006b) provide further evidence that ice residue and background aerosol were not recently injected from the lower troposphere.

Preferential ice formation on larger aerosols has been predicted theoretically (Pruppacher and Klett, 1997; Koop et al., 2000) and observed for both homogeneous (Cziczo et al., 2004a) and heterogeneous mechanisms (Archuleta et al., 2005; Gallavardin et al., 2008). Since cirrus residues were not chemically distinct, one might expect that only the largest sulfate-organic aerosols froze to form SVC. However, SVC residues detected by PALMS were not significantly larger than unfrozen aerosols (Fig. 5c). We presume that aerosol composition is fairly homogeneous across the accumulation mode, and that it is therefore unlikely that aerosols below the detection range would dominate ice nucleation via a different mechanism. This is probably a good assumption since long residence times in the TTL will act to homogenize sulfateorganic particles in the accumulation mode.

Ice residue data from other SVC encounters during CRAVE are consistent with the 2 February measurements (Table 1). To augment the limited residue dataset, particle type classifications were also determined for negative ion spectra, although classification is less selective than for positive spectra. Particles with biomass burning or meteoric material cannot be differentiated from sulfate-organic particles in negative ion mode. Nevertheless, the negative ion particle types are consistent with positive ion data: the vast majority of ice residues and unfrozen aerosols were sulfate-organic internal mixtures with very low abundances of mineral dust and sea salt.

\section{Nucleation near the tropical tropopause}

Unlike controlled laboratory experiments of ice nucleation, ice onset conditions for SVC encountered in flight cannot be accurately determined. Assuming that vertical displacement was $<1 \mathrm{~km}$ since SVC formation, ice initiation occurred in the temperature range 185-200 K. Despite uncertainties regarding ice onset conditions, we can make several definitive statements about the nucleation mechanism.

The microphysics of these SVC are not easily explained by either conventional homogeneous or heterogeneous freezing. In situ water vapor measurements indicated ice saturation levels (RHi) up to $130 \%$ within and near SVC, below the $160-165 \%$ level where homogeneous freezing of soluble aerosols is predicted (Fig. 3). Aerosol concentrations $(d>100 \mathrm{~nm})$ within the 2 February SVC, were $\sim 10 \mathrm{~cm}^{-3}$ 

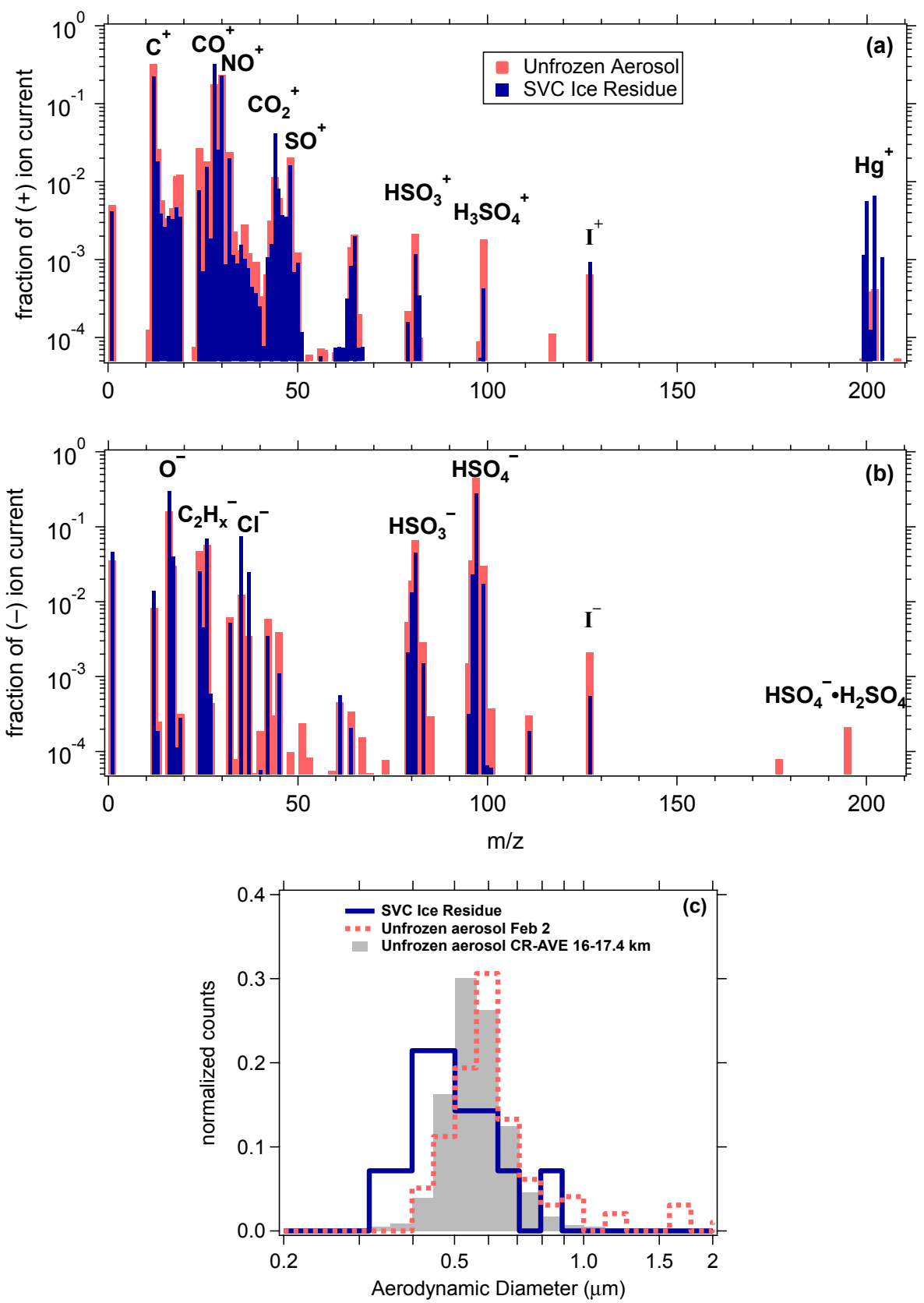

Fig. 5. Chemical and size comparisons between subvisible cirrus crystal residues and unfrozen aerosols for the SVC layer at $16.0-17.4 \mathrm{~km}$ on 2 February. Average positive (a) and negative (b) ion mass spectra for sulfate-organic aerosol particles. Broad chemical signatures as well as minor components detected by PALMS show negligible difference. (c) Aerodynamic diameter measurements show no preference for freezing of larger diameter aerosols. The falloff at $0.3-0.4 \mu \mathrm{m}$ is due to decreasing detection efficiency. The background TTL aerosol distribution was characterized by weak nucleation $(\sim 4 \mathrm{~nm})$ and Aiken $(\sim 25 \mathrm{~nm})$ modes and a broad accumulation mode (Froyd et al., 2009). The PALMS distribution in (c) represents the upper end of this accumulation mode.

compared to ice crystal concentrations of $\sim 20-50 \mathrm{~L}^{-1}$, indicating that only 1 in $\sim 200-500$ aerosol particles froze. This selectivity is not consistent with homogeneous freezing that tends to activate a large fraction of accumulation mode aerosols within a very narrow relative humidity range. A more detailed analysis has been performed by Jensen et al. (2009b). In their simulations homogeneous freezing produced far higher fractions of freezing aerosol than were observed during CR-AVE.

A low ice crystal number concentration can be formed in SVC if only a small subset of aerosol freezes at ice saturations below the homogeneous threshold (Krämer et al., 
2009). However, that would normally imply that some particles had unique compositions to serve as effective IN, which was not observed. Our results suggest that at tropopause temperatures some sulfate-organic particles possess an unseen advantage to freezing and can freeze via a heterogeneous mechanism. Furthermore, the sulfate-organic aerosols that did freeze were more effective IN than other aerosol types including mineral dust. We previously estimated the average TTL mineral dust concentration outside cloud during CRAVE to be $\sim 5 \mathrm{~L}^{-1}$ (Froyd et al., 2009). Even if all the mineral dust aerosols froze, they could not generate the crystal concentrations in SVC.

Recent laboratory studies have identified novel nucleation mechanisms that may be relevant to freezing of sulfateorganic aerosols in the tropical tropopause region. There is evidence that dry ammonium sulfate aerosols can act as efficient heterogeneous ice nuclei (Abbatt et al., 2006), freezing at ice saturations up to $45 \%$ below the homogeneous threshold. Upon gradual ascent through the TTL, it is likely (Jensen et al., 2009b) that a pure ammonium sulfate aerosol would experience a relative humidity over liquid water RHw $<35 \%$, at which point it would effloresce. At temperatures below about $205 \mathrm{~K}$ the deliquescence relative humidity for pure ammonium sulfate becomes higher than that required for homogeneous freezing (Fortin et al., 2002) so that efflorescence is effectively irreversible. PALMS measurements suggest that the sulfate in these aerosols was nearly or fully neutralized. Although PALMS cannot determine the phase of these ammonium sulfate aerosols, impactor samples from the subtropical stratosphere have occasionally yielded electron microscope images indicative of dry ammonium sulfate (Gras, 1978; Bigg, 1986). All the ice residuals also contained organics, which will likely suppress heterogeneous freezing (Mohler et al., 2008). However, ammonium sulfate aerosols that are only partially coated and have exposed surface sites may still be IN-active.

In other experimental studies, organic species thought to be representative of upper tropospheric aerosol material formed highly viscous 'glasses' at low temperatures (Murray, 2008; Zobrist et al., 2008). These glassy aerosols resisted water uptake and did not freeze at ice saturation levels greater than those for conventional homogeneous freezing. However, recent experiments at the AIDA expansion chamber (Murray et al., 2009) show that small fractions of these glassy aerosols can act as heterogeneous nuclei, forming ice crystals at saturation levels significantly lower than homogeneous freezing. At $200 \mathrm{~K}$ ice formation was observed for RHi as low as $120 \%$, and at $135 \%, \sim 1$ in 1000 glassy aerosols froze.

\section{Summary}

It is clear that the subvisible cirrus observed throughout this study did not form via a 'conventional' nucleation mechanism such as ice deposition on mineral dust or homogeneous freezing of sulfuric acid solutions. Accumulation mode aerosols in the TTL are principally mixtures of partially or fully neutralized sulfate with organic material. A small fraction of these aerosols freeze to form ice crystals and generate subvisible cirrus at the tropopause. The iceforming aerosols do not appear chemically distinct, nor are they larger than background aerosols. In contrast to previous observations, high organic content did not inhibit freezing. Heterogeneous nucleation involving either dry ammonium sulfate or glassy organic aerosols are both plausible mechanisms to initiate ice formation and ultimately generate SVC clouds. It is worth noting that deep continental convection sporadically penetrates the TTL (Alcala and Dessler, 2002) and may exert a disproportionally strong influence on aerosol properties in the tropopause region (Froyd et al., 2009). TTL cirrus formed subsequent to these injection events may therefore proceed via different mechanisms than the tropopause level SVC described here.

Acknowledgements. The authors thank Eric Jensen and Benjamin Murray for their valuable input. This work was funded by NOAA base and climate change programs as well as NASA funding for aircraft deployments. Work performed at the Jet Propulsion Laboratory, California Institute of Technology, was under a contract with NASA.

Edited by: R. MacKenzie

\section{References}

Abbatt, J. P. D., Benz, S., Cziczo, D. J., Kanji, Z., Lohmann, U., and Mohler, O.: Solid ammonium sulfate aerosols as ice nuclei: A pathway for cirrus cloud formation, Science, 313, 1770-1773, 2006.

Alcala, C. M. and Dessler, A. E.: Observations of deep convection in the tropics using the Tropical Rainfall Measuring Mission (TRMM) precipitation radar, J. Geophys. Res-Atmos., 107, 4792, doi:10.1029/2002JD002457, 2002.

Archuleta, C. M., DeMott, P. J., and Kreidenweis, S. M.: Ice nucleation by surrogates for atmospheric mineral dust and mineral dust/sulfate particles at cirrus temperatures, Atmos. Chem. Phys., 5, 2617-2634, 2005, http://www.atmos-chem-phys.net/5/2617/2005/.

Baumgardner, D., Jonsson, H., Dawson, W., O'Connor, D., and Newton, R.: The cloud, aerosol and precipitation spectrometer: a new instrument for cloud investigations, Atmos. Res., 59, 251264, 2001.

Bigg, E. K.: Ammonium compounds in stratospheric aerosols, Tellus, 38B, 62-66, 1986.

Comstock, J. M., Ackerman, T. P., and Mace, G. G.: Ground-based lidar and radar remote sensing of tropical cirrus clouds at Nauru 
Island: Cloud statistics and radiative impacts, J. Geophys. Res.Atmos., 107, 4714, doi:10.1029/2002JD002203, 2002.

Cziczo, D. J., DeMott, P. J., Brooks, S. D., Prenni, A. J., Thomson, D. S., Baumgardner, D., Wilson, J. C., Kreidenweis, S. M., and Murphy, D. M.: Observations of organic species and atmospheric ice formation, Geophys. Res. Lett., 31, L12116, doi:10.1029/2004GL019822, 2004a.

Cziczo, D. J., Murphy, D. M., Hudson, P. K., and Thomson, D. S.: Single particle measurements of the chemical composition of cirrus ice residue during CRYSTAL-FACE, J. Geophys. Res.Atmos., 109, D04201, doi:10.1029/2003JD004032, 2004b.

Cziczo, D. J., Froyd, K. D., Gallavardin, S. J., Mohler, O., Benz, S., Saathoff, H., and Murphy, D. M.: Deactivation of ice nuclei due to atmospherically relevant surface coatings, Environ. Res. Lett., 4, 044013, doi:10.1088/1748-9326/4/4/044013, 2009.

Dessler, A. E. and Yang, P.: The distribution of tropical thin cirrus clouds inferred from terra MODIS data, J. Climate, 16, 12411247, 2003.

Dessler, A. E., Palm, S. P., Hart, W. D., and Spinhirne, J. D.: Tropopause-level thin cirrus coverage revealed by ICESat/Geoscience Laser Altimeter System, J. Geophys. Res.Atmos., 111, D08203, doi:10.1029/2005JD006586, 2006.

Fortin, T. J., Shilling, J. E., and Tolbert, M. A.: Infrared spectroscopic study of the low-temperature phase behavior of ammonium sulfate, J. Geophys. Res.-Atmos., 107, 4088, doi:10.1029/2001JD000677, 2002.

Froyd, K. D., Murphy, D. M., Sanford, T. J., Thomson, D. S., Wilson, J. C., Pfister, L., and Lait, L.: Aerosol composition of the tropical upper troposphere, Atmos. Chem. Phys., 9, 4363-4385, 2009 ,

http://www.atmos-chem-phys.net/9/4363/2009/.

Fueglistaler, S., Dessler, A. E., Dunkerton, T. J., Folkins, I., Fu, Q., and Mote, P. W.: Tropical Tropopause Layer, Rev. Geophys., 47, RG1004, doi:10.1029/2008RG000267, 2009.

Gallavardin, S. J., Froyd, K. D., Lohmann, U., Moehler, O., Murphy, D. M., and Cziczo, D. J.: Single Particle Laser Mass Spectrometry Applied to Differential Ice Nucleation Experiments at the AIDA Chamber, Aerosol Sci. Tech., 42, 773-791, 2008.

Garrett, T. J., Heymsfield, A. J., McGill, M. J., Ridley, B. A., Baumgardner, D. G., Bui, T. P., and Webster, C. R.: Convective generation of cirrus near the tropopause, J. Geophys. Res.-Atmos., 109, D21203, doi:10.1029/2004JD004952, 2004.

Gras, J. L.: Change in nature of stratospheric aerosol collected at 34 ${ }^{\circ} \mathrm{S}$, Nature, 271, 231-232, doi:10.1038/271231a0, 1978.

Hartmann, D. L., Holton, J. R., and Fu, Q.: The heat balance of the tropical tropopause, cirrus, and stratospheric dehydration, Geophys. Res. Lett., 28, 1969-1972, 2001.

Hudson, P. K., Murphy, D. M., Cziczo, D. J., Thomson, D. S., de Gouw, J. A., Warneke, C., Holloway, J., Jost, J. R., and Hubler, G.: Biomass-burning particle measurements: Characteristic composition and chemical processing, J. Geophys. Res.Atmos., 109, D23S27, doi:10.1029/2003JD004398, 2004.

Jensen, E., and Pfister, L.: Transport and freeze-drying in the tropical tropopause layer, J. Geophys. Res.-Atmos., 109, D02207, doi:10.1029/2003JD004022, 2004.

Jensen, E. J., Toon, O. B., Pfister, L., and Selkirk, H. B.: Dehydration of the upper troposphere and lower stratosphere by subvisible cirrus clouds near the tropical tropopause, Geophys. Res. Lett., 23, 825-828, 1996.
Jensen, E. J., Toon, O. B., Vay, S. A., Ovarlez, J., May, R., Bui, T. P., Twohy, C. H., Gandrud, B. W., Pueschel, R. F., and Schumann, U.: Prevalence of ice-supersaturated regions in the upper troposphere: Implications for optically thin ice cloud formation, J. Geophys. Res.-Atmos., 106, 17253-17266, 2001.

Jensen, E. J., Smith, J. B., Pfister, L., Pittman, J. V., Weinstock, E. M., Sayres, D. S., Herman, R. L., Troy, R. F., Rosenlof, K., Thompson, T. L., Fridlind, A. M., Hudson, P. K., Cziczo, D. J., Heymsfield, A. J., Schmitt, C., and Wilson, J. C.: Ice supersaturations exceeding $100 \%$ at the cold tropical tropopause: implications for cirrus formation and dehydration, Atmos. Chem. Phys., 5, 851-862, 2005, http://www.atmos-chem-phys.net/5/851/2005/.

Jensen, E. J., Pfister, L., Bui, T. V., Lawson, P., Baker, B., Mo, Q., Baumgardner, D., Weinstock, E. M., Smith, J. B., Moyer, E. J., Hanisco, T. F., Sayres, D. S., Clair, J. M. St., Alexander, M. J., Toon, O. B., and Smith, J. A.: Formation of large $(\simeq 100 \mu \mathrm{m})$ ice crystals near the tropical tropopause, Atmos. Chem. Phys., 8, 1621-1633, 2008, http://www.atmos-chem-phys.net/8/1621/2008/.

Jensen, E. J., Lawson, P., Baker, B., Pilson, B., Mo, Q., Heymsfield, A. J., Bansemer, A., Bui, T. P., McGill, M., Hlavka, D., Heymsfield, G., Platnick, S., Arnold, G. T., and Tanelli, S.: On the importance of small ice crystals in tropical anvil cirrus, Atmos. Chem. Phys., 9, 5519-5537, 2009, http://www.atmos-chem-phys.net/9/5519/2009/.

Jensen, E. J., Pfister, L., Bui, T.-P., Lawson, P., and Baumgardner, D.: Ice nucleation and cloud microphysical properties in tropical tropopause layer cirrus, Atmos. Chem. Phys. Discuss., 9, 2063120675, 2009,

http://www.atmos-chem-phys-discuss.net/9/20631/2009/.

Kärcher, B.: Properties of subvisible cirrus clouds formed by homogeneous freezing, Atmos. Chem. Phys. Discuss., 2, 357-383, 2002 ,

http://www.atmos-chem-phys-discuss.net/2/357/2002/.

Kärcher, B.: Cirrus clouds in the tropical tropopause layer: Role of heterogeneous ice nuclei, Geophys. Res. Lett., 31, L12101, doi:10.1029/2004GL019774, 2004.

Koop, T., Luo, B. P., Tsias, A., and Peter, T.: Water activity as the determinant for homogeneous ice nucleation in aqueous solutions, Nature, 406, 611-614, 2000.

Krämer, M., Schiller, C., Afchine, A., Bauer, R., Gensch, I., Mangold, A., Schlicht, S., Spelten, N., Sitnikov, N., Borrmann, S., de Reus, M., and Spichtinger, P.: Ice supersaturations and cirrus cloud crystal numbers, Atmos. Chem. Phys., 9, 3505-3522, 2009,

http://www.atmos-chem-phys.net/9/3505/2009/.

Lawson, R. P., O’Connor, D., Zmarzly, P., Weaver, K., Baker, B., Mo, Q. X., and Jonsson, H.: The 2D-S (Stereo) probe: Design and preliminary tests of a new airborne, high-speed, highresolution particle Imaging probe, J. Atmos. Ocean. Tech., 23, 1462-1477, 2006.

Lawson, R. P., Pilson, B., Baker, B., Mo, Q., Jensen, E., Pfister, L., and Bui, P.: Aircraft measurements of microphysical properties of subvisible cirrus in the tropical tropopause layer, Atmos. Chem. Phys., 8, 1609-1620, 2008, http://www.atmos-chem-phys.net/8/1609/2008/.

Liu, C. T.: Geographical and seasonal distribution of tropical tropopause thin clouds and their relation to deep convection and 
water vapor viewed from satellite measurements, J. Geophys. Res.-Atmos., 112, D09205, doi:10.1029/2006JD007479, 2007.

Luo, B. P., Peter, T., Fueglistaler, S., Wernli, H., Wirth, M., Kiemle, C., Flentje, H., Yushkov, V. A., Khattatov, V., Rudakov, V., Thomas, A., Borrmann, S., Toci, G., Mazzinghi, P., Beuermann, J., Schiller, C., Cairo, F., Di Donfrancesco, G., Adriani, A., Volk, C. M., Strom, J., Noone, K., Mitev, V., MacKenzie, R. A., Carslaw, K. S., Trautmann, T., Santacesaria, V., and Stefanutti, L.: Dehydration potential of ultrathin clouds at the tropical tropopause, Geophys. Res. Lett., 30, 1557, doi:10.1029/2002GL016737, 2003.

Massie, S., Gettelman, A., Randel, W., and Baumgardner, D.: Distribution of tropical cirrus in relation to convection, J. Geophys. Res.-Atmos., 107, 4591, doi:10.1029/2001JD001293, 2002.

May, R. D.: Open-path, near-infrared tunable diode laser spectrometer for atmospheric measurements of H2O, J. Geophys. Res.Atmos., 103, 19161-19172, 1998.

McFarquhar, G. M., Heymsfield, A. J., Spinhirne, J., and Hart, B.: Thin and subvisual tropopause tropical cirrus: Observations and radiative impacts, J. Atmos. Sci., 57, 1841-1853, 2000.

Mohler, O., Benz, S., Saathoff, H., Schnaiter, M., Wagner, R., Schneider, J., Walter, S., Ebert, V., and Wagner, S.: The effect of organic coating on the heterogeneous ice nucleation efficiency of mineral dust aerosols, Environ. Res. Lett., 3, 025007 , doi:10.1088/1748-9326/3/2/025007, 2008.

Murphy, D. M., Cziczo, D. J., Hudson, P. K., Thomson, D. S., Wilson, J. C., Kojima, T., and Buseck, P. R.: Particle generation and resuspension in aircraft inlets when flying in clouds, Aerosol Sci. Tech., 38, 400-408, 2004.

Murphy, D. M. and Koop, T.: Review of the vapour pressures of ice and supercooled water for atmospheric applications, Q. J. Roy. Meteor. Soc., 131, 1539-1565, 2005.

Murphy, D. M., Cziczo, D. J., Froyd, K. D., Hudson, P. K., Matthew, B. M., Middlebrook, A. M., Peltier, R. E., Sullivan, A., Thomson, D. S., and Weber, R. J.: Single-particle mass spectrometry of tropospheric aerosol particles, J. Geophys. Res.-Atmos., 111, D23S32, doi:10.1029/2006JD007340, 2006a.

Murphy, D. M., Hudson, P. K., Thomson, D. S., Sheridan, P. J., and Wilson, J. C.: Observations of mercury-containing aerosols, Environ. Sci. Technol., 40, 3163-3167, 2006b.

Murray, B. J.: Inhibition of ice crystallisation in highly viscous aqueous organic acid droplets, Atmos. Chem. Phys., 8, 54235433, 2008, http://www.atmos-chem-phys.net/8/5423/2008/
Murray, B. J., Wilson, T. W., Dobbie, S., Cui, Z., Möhler, O., Schnaiter, M., Wagner, R., Benz, S., Niemand, M., Saathoff, H., Ebert, V., Wagner, S., and Kärcher, B.: Glassy aerosols modify tropical tropopause cirrus and humidity, in preparation, 2009.

Park, S., Jimnez, R., Daube, B. C., Pfister, L., Conway, T. J., Gottlieb, E. W., Chow, V. Y., Curran, D. J., Matross, D. M., Bright, A., Atlas, E. L., Bui, T. P., Gao, R.-S., Twohy, C. H., and Wofsy, S. C.: The $\mathrm{CO}_{2}$ tracer clock for the Tropical Tropopause Layer, Atmos. Chem. Phys., 7, 3989-4000, 2007, http://www.atmos-chem-phys.net/7/3989/2007/.

Pfister, L., Selkirk, H. B., Jensen, E. J., Schoeberl, M. R., Toon, O. B., Browell, E. V., Grant, W. B., Gary, B., Mahoney, M. J., Bui, T. V., and Hintsa, E.: Aircraft observations of thin cirrus clouds near the tropical tropopause, J. Geophys. Res.-Atmos., 106, 9765-9786, 2001.

Pruppacher, H. R. and Klett, J. D.: Microphysics of clouds and precipitation, 2nd rev. ed., Atmospheric and oceanographic sciences library, v. 18, Kluwer Academic Publishers, Dordrecht; Boston, 954 pp., 1997.

Ridley, B., Atlas, E., Selkirk, H., Pfister, L., Montzka, D., Walega, J., Donnelly, S., Stroud, V., Richard, E., Kelly, K., Tuck, A., Thompson, T., Reeves, J., Baumgardner, D., Rawlins, W. T., Mahoney, M., Herman, R., Friedl, R., Moore, F., Ray, E., and Elkins, J.: Convective transport of reactive constituents to the tropical and mid-latitude tropopause region: I. Observations, Atmos. Environ., 38, 1259-1274, 2004.

Schwartz, C. and Mace, G. G.: Co-occurrence statistics of tropical tropopause layer cirrus with lower cloud layers as derived from CloudSat and CALIPSO data, J. Geophys. Res.-Atmos., submitted, 2009.

Thomson, D. S., Schein, M. E., and Murphy, D. M.: Particle analysis by laser mass spectrometry WB-57F instrument overview, Aerosol Sci. Tech., 33, 153-169, 2000.

Troy, R. F.: Field studies of ice supersaturations in the tropical tropopause layer, Ph.D. Thesis, Geophysics and Space Physics, University of California at Los Angeles, 2007.

Zobrist, B., Marcolli, C., Pedernera, D. A., and Koop, T.: Do atmospheric aerosols form glasses?, Atmos. Chem. Phys., 8, 52215244, 2008,

http://www.atmos-chem-phys.net/8/5221/2008/. 